\title{
PENGARUH AUDIT INTERNAL TERHADAP GOOD CORPORATE GOVERNANCE PADA BUMN
}

\author{
Oleh: \\ Toni Heryana \\ (Dosen Prodi Akuntansi FPEB Universitas Pendidikan Indonesia) \\ Vita Novrita \\ (Alumni Prodi Akuntansi FPEB Universitas Pendidikan Indonesia)
}

\begin{abstract}
s
This research is being purposed to know how the implementation of Internal Audit in $B U M N$, to recognize the operating of Good Corporate Governance in BUMN and to determine the influence of internal audit of Good Corporate Governance in BUMN.The research method used in the study is descriptive-verification. The sampling technique used in the study is non-probability sampling; it is a technique which not provides equal opportunities or chances to each element or member of the population to be elected as a sample member due to certain considerations. In testing the hypothesis the writer used "Rank Spearman". The finding showed that BUMN in Bandung has been running its activities in accordance with professional standards of internal audit with the result calculation of $86.76 \%$. Good Corporate Governance in Bandung's BUMN was conducted based on the principles of good corporate governance with the result calculation of $90.88 \%$.

Based on hypothesis testing's result; it is resulted 0.711 of correlation coefficient which means there is strong relationship between the internal auditors of Good Corporate Governance in Bandung's BUMN. The result of determination coefficient of variable $X$ to variable $Y$ is $50.55 \%$. It indicates that the influence of internal audit of Good Corporate Governance is in amount of 59.44\%. It also shows positive relationship means that if internal audit has been carried out properly, then the Good Corporate Governance is performing well.
\end{abstract}

Keywords: Internal Auditor, Good Corporate Governance.

\section{Latar Belakang}

Badan Usaha Milik Negara (BUMN) adalah badan usaha yang sebagian atau seluruh kepemilikannya dimiliki oleh Negara Republik Indonesia. BUMN sebagai agent of development diharapkan dapat menjadi motor penggerak yang dapat membantu mempercepat pemulihan perekonomian nasional melalui penerapan praktik-praktik Good Corporate Governance (GCG). Budaya Bisnis yang sehat dan komitmen manajemen yang kuat sangat dibutuhkan oleh BUMN agar mampu bertahan dalam persaingan global maka dibutuhkan budaya GCG atau tata kelola perusahaan.

Begitu banyak perusahaan yang gulung tikar akibat tidak terwujudnya GCG. Salah satu penyebab bangkrutnya perusahaan yaitu adanya praktik Korupsi, Kolusi dan Nepotisme (KKN). Menurut Tirmidzi', GCG di Indonesia belum bisa mencapai kata "good".

\footnotetext{
${ }^{1}$ Seminar tentang Good Corporate Governance ( $G C G$ ) dan modelling GCG pada 3 Juli 2009
} 
Sementara menurut kajian Pricewaterhouse Coopers yang dimuat dalam Report on Institutional Investor Survey (2002) menempatkan Indonesia di urutan paling bawah bersama China dan India dengan nilai 1,96 untuk transparansi dan keterbukaan. Laporan tentang GCG oleh CLSA (2003), menempatkan Indonesia di urutan terbawah dengan skor 1,5 untuk masalah penegakan hukum, 2,5 untuk mekanisme institusional dan budaya GCG, dan dengan total 3,2. Meskipun skor Indonesia di tahun 2004 lebih baik dibandingkan dengan 2003, kenyataannya Indonesia masih tetap berada di urutan terbawah di antara Negara-negara Asia. Faktor-faktor penyebab rendahnya kinerja Indonesia adalah penegakan hukum dan budaya corporate governance yang masih berada di titik paling rendah di antara Negara-negara lain yang sedang tumbuh di Asia. (Jurnal Manajemen dan Kewirausahaan, VOL.8, NO. 1, Maret 2006: 1-9).

Seharusnya BUMN sebagai badan publik yang sangat dekat dengan kebebasan memperoleh informasi publik memiliki kewajiban untuk menyediakan informasi yang dapat diakses oleh masyarakat, dalam rangka meningkatkan transparansi dan mencegah korupsi. Pemahaman tersebut membuka wawasan bahwa korporat kita belum dikelola secara benar dan penerapan GCG belum optimal.

Good Corporate Governance didefinisikan sebagai hubungan antara suatu perusahaan dengan pemegang sahamnya. Menurut keputusan Mentri BUMN No. KEP 117 /M-MBU/2002 GCG adalah suatu proses dan struktur yang digunakan oleh organ BUMN untuk meningkatkan keberhasilan usaha dan akuntabilitas perusahaan guna mewujudkan nilai pemegang saham dalam jangka panjang dengan memperhatikan kepentingan stakeholder lainnya, berlandaskan peraturan perundangan dan nilai-nilai etika. Jadi fungsi GCG membantu mencapai tujuan perusahaan.

Fungsi audit internal yang efektif diyakini mampu memberikan dukungan terhadap peningkatan GCG, pengelolaan resiko, dan pengendalian manajemen. Internal auditor merupakan dukungan bagi Komisaris, Komite Audit, Direksi dan Manajemen untuk mengembangkan GCG.

BUMN wajib menembangkan fungsi internal audit yang efektif guna membantu pihak manajemen melakukan proses penilaian resiko dan pengendalian internal. Fungsi internal audit yang efektif harus memiliki karakteristik independen, mempunyai staf yang kompeten, di dukung sumber daya yang memadai. Fungsi internal audit memberikan penilaian atas pengendalian internal dan proses pengelolaan resiko.

Tujuan dari pemeriksaan internal adalah membantu para anggota organisasi agar dapat melakukan tanggung jawab secara efektif. Pemeriksaan internal akan melakukan analisis, penilaian dan pengajuan saran-saran. Tujuan pemeriksaan intern mencakup pula pengembangan pengawasan yang efektif dengan biaya yang wajar.

Beberapa masalah yang kemudian timbul berkaitan dengan Audit Internal adalah seberapa efektif keberadaan audit internal dalam memberikan nilai tambah bagi perusahaan. The Institute of Internal Auditors (IIA) menjawabnya dengan menetapkan kriteria dan standar profesi Audit Internal harus mampu menjaga profesi agar memberikan nilai tambah bagi perusahaan.

Namun di Indonesia masih ada auditor yang menjalankan profesinya tidak berdasarkan kualifikasi seperti apa yang diungkapkan oleh Hiro Tugiman berikut ini:

Sampai saat ini uncertified internal auditor dapat saja menandatangani laporan auditnya. Banyak auditor Indonesia ditunjuk oleh pimpinan organisasinya bukan berdasarkan kualifikasi seseorang dalam audit internal, melainkan karena perannya. Masih banyak sikap auditor internal yang mengharapkan kesuksesan dengan menyampaikan temuan dan menyajikan hal-hal yang tidak mengenakan auditee dan manajer. Tidak sedikit auditor internal melaksanakannya tugasnya dengan suatu perselisihan, serta menonjolkan kewerangan yang melekat pada dirinya. (Hiro Tugiman, 2006: 2) 
Sikap profesional patut diperlukan oleh seorang auditor dengan adanya monitoring. Monitoring dibutuhkan perusahaan dalam rangka penilaian terhadap internal audit pada setiap tingkat unit struktur BUMN, sehingga dapat dilaksanakan secara optimal, dengan ketentuan bahwa penyimpangan disampaikan kepada komite audit seperti yang tercantum dalam keputusan menteri BUMN tentang peneraapan praktek GCG dalam BUMN pasal 22 tentang pengendalian internal.

Sejalan dengan pengendalian internal, para ahli berkeyakinan bahwa dengan dukungan audit internal yang professional dapat memperbaiki proses dan pengendalian manajemen sehingga membantu pimpinan untuk memaksimalkan kinerja perusahaan untuk keuntungan manjemen dan para stakeholder sehingga audit internal turut serta mendorong terlaksananya implementasi GCG di BUMN.

Berdasarkan fenomena diatas maka penulis tertarik menulis skripsi mengenai pengaruh audit internal terhadap GCG, dengan judul "Pengaruh Audit Internal terhadap Good Corporate Governance pada BUMN"

\section{Rumusan Masalah} sebagai berikut:

Berdasarkan permasalahan tersebut penulis dapat merumuskan pertanyaan

1. Bagaimanakah Pelaksanaan Audit Internal pada BUMN?

2. Bagaimanakah Pelaksanaan Good Corporate Governance pada BUMN?

3. Seberapa besar pengaruh Audit Internal terhadap Good Corporate Governance pada BUMN?

\section{Kerangka Pemikiran}

Audit internal adalah aktivitas pemberian keyakinan obyektif yang independen dan aktivitas konsultasi yang dilakukan untuk memberikan nilai tambah dan meningkatkan kinerja operasi organisasi. Aktivitas tersebut membantu organisasi mencapai tujuannya dengan melaksanakan pendekatan yang sistematis dan berdisiplin untuk mengevaluasi dan meningkatkan efektivitas, manajemen resiko, kecukupan control, dan proses tata kelola. Sawyer (2009: 21)Kegiatan pemeriksaan internal dilaksanakan dalam berbagai lingkungan yang berbeda dalam organisasi yang tujuan, ketentuan, dan kebiasaannya tidak sama, maka akan mempengaruhi pemeriksaan internal di masingmasing lingkungan.Menurut IIA, Hiro Tugiman (2006: 13-14) standar profesi audit internal meliputi: (1) Independensi atau kemandirian unit audit internal yang membuatnya terpisah dari berbagai kegiatan yang diperiksa objektivitas para pemeriksa internal; (2) Keahlian penggunaan kemahiran professional secara cermat dan seksama auditor internal; (3) Lingkup pekerjaan audit internal; (4) Pelaksanaan tugas audit internal; (5) Manajemen audit internal.

Corporate governance menurut $O E D C$ adalah sistem yang dipergunakan untuk mengerahkan dan mengendalikan kegiatan bisnis perusahaan. Corporate governance mengatur pembagian tugas, hak kewajiban mereka yang berkepentingan terhadap kehidupan perusahaan, termasuk para pemegang saham, Dewan Pengurus, para manajer, dan semua anggota stakeholder. Sutojo dan E John (2008: 2)

Berdasarkan KEP -117/M-MBU /2002 tentang penerapan praktik GCG pada BUMN adalah sebagai berikut: (1) Transparansi yaitu keterbukaan dalam melaksanakan proses pengambilan keputusan dan keterbukaan dalam merngungkapakan informasi material dan relevan mengenai perusahaan; (2) Kemandirian yaitu keadaan dimana perusahaan dikelola secara profesional tanpa benturan kepentingan dan pengaruh atau tekanan dari pihak manapun yang tidak sesuai dengan peraturan perundang-undangan dan prinsip-prinsip korporasi yang sehat; (3) Akuntabilitas yaitu kejelasan fungsi pelaksanaan 
dan pertanggungjawaban organisasi sehingga pengelolaan perusahaan terlaksana secara efektif; (4) Pertanggungjawaban yaitu kesesuaian dalam pengelolaan perusahaan terhadap peraturan perundang-undangan dan prinsip korporasi; (5) Kewajaran yaitu Keadaan dan kesetaraan dalam memenuhi hak-hak stakeholder yang timbul berdasarkan perjanjian dan perundangan yang berlaku.

Auditor internal sebagai salah satu profesi yang menunjang terwujudnya GCG, saat ini telah berkembang menjadi komponen utama dalam mewujudkan pengelolaan perusahaan yang sehat. Keterkaitan audit internal dengan GCG dapat dilihat dari definisi, tujuan, ruang lingkup, wewenang, tugas dan tanggung jawab audit internal dihubungkan dengan prinsip-prinsip GCG. Menurut Iman S. Tunggal dan Amin W. Tunggal (2002: 49) auditor internal dapat berperan dalam hal berikut, antara lain:

1. Sebagai Compliance auditor

a. Bertanggungjawab kepada dirktur utama/ Chief Executive Officer (CEO) dan mempunyai akses kepada komite audit.

b. Memonitor pelaksanaan kepatuhan terhadap kebijakan prosedur perusahaan

c. Mengevaluasi sistem pengendalian internal dan bertanggungjawab kepada komite audit.

d. Memelihara dan mengamankan aktiva perusahaan dan menangani factor resiko secara baik.

e. Menelaah kinerja melalui mekanisme audit keuangan dan operasional

\section{Sebagai internal business consultant}

a. Membantu komite audit dalam menilai resiko dan memberi nasihat kepada pihak manajemen

b. Melaksanakan fungsi konsultan dan memastikan pelaksanaan GCG Menelaah peraturan corporate governance minimal setahun sekali.

Peran akuntan perusahaan sangat dibutuhkan, baik peran dari akuntan manajemen maupun audit internal. Dilihat dari jenis audit Arens dan Loebbecke membagi pekerjaan audit menjadi tiga golongan, yaitu: Audit laporan keuangan, audit operasional, dan audit kepatuhan. (Arens at all, 16: 2008). Sedangkan jenis-jenis audit pemerintah yang mana termasuk BUMN diidentifikasikan dalam Government Auditing Standards yang didalamnya mencakup tentang audit kinerja. Berdasarkan fungsi audit, audit ketaatan,audit operasional dan audit kinerja merupakan pendukung dari diterapkannya prinsip GCG.

Sehingga dapat dikatakan bahwa audit internal bertugas meneliti dan mengevaluasi bekerjanya sistem akuntansi dan berperan terhadap terlaksananya GCG di perusahaan. Dimana dituntut untuk mempunyai wawasan yang luas terhadap perusahaan, yang salah satunya membuat desain Sistem Pengendalian Manajemen serta melaporkannya ke Komite Audit.

Audit internal diperlukan sebagai alat untuk memonitor secara terus menerus apakah pengendalian internal yang ada dalam perusahaan telah berjalan sebagaimana mestinya. Secara umum audit internal adalah audit yang tidak memihak (Independent), yang dilakukan oleh seseorang atau beberapa orang yang menjadi pegawai dan memiliki keahlian khusus di bidang audit internal. Adapun pengertian audit internal menurut beberapa para ahli sebagai berikut:

Internal audit adalah pemeriksaan yang dilakukan oleh bagian internal audit perusahaan, baik terhadap laporan keuangan dan catatan akuntansi perusahaan, maupun ketaatan terhadap kebijakan manajemen puncak yang telah ditentukan dan ketaatan terhadap peraturan pemerintah dan ketentuan-ketentuan dari ikatan profesi yang berlaku. (Agoes, 2008: 221): 
Definisi ini mengandung pengertian bahwa audit internal merupakan suatu aktivitas yang dilakukan untuk membantu manajemen dalam penyediaan informasi tentang berfungsinya pengendalian intern, dengan tujuan akhir yaitu menambah nilai perusahaan. Pelaksanaan audit internal dilakukan secara independen terhadap lini fungsi organisasi dan obyektif yang berarti tidak terpengaruh oleh pihak manapun dan tidak terlibat dalam pelaksanaan kegiatan yang diaudit. Hasil audit yang diperoleh dari pelaksanaan audit internal secara independen dan obyektif tersebut akan dapat diandalkan oleh para pengguna informasi.

Dari uraian dapat diketahui bahwa audit internal merupakan alat bantu bagi pimpinan perusahaan dalam mengukur dan mengevaluasi keefektifan dari pengendalian perusahaan yang telah diterapkan. Sehingga mencerminkan pencapaian tujuan perusahaan, serta mengevaluasi dan meningkatkan manajemen resiko, pengendalian dan proses pengaturan serta pengelolaan organisasi.

standar.

Agar terciptanya audit internal yang baik maka perlu dipenuhi suatu kriteria atau

Berikut merupakan standar profesi audit internal sebagai berikut: (1) Independensi : audit internal harus mandiri dan terpisah dari kegiatan yang diperiksanya; (2) Kemampuan Profesional : audit internal harus mencerminkan keahlian dan ketelitian professional; (3) Lingkup Pekerjaan: lingkup pekerjaan auditor internal harus meliputi penngujian dan evaluasi terhadap kecukupan serta efektivitas sistem pengendalian internal yang dimiliki organisasi dan kualitas pelaksanaan tanggung jawab yang diberikan; (4) Pelaksanaan Kegiatan Pemeriksaan: kegiatan pemeriksaan harus meliputi perencanaan pemeriksaan, pengujian, serata pengevaluasian informasi pemberitahuan hasil dan menindak lanjuti; (5) Manajemen Bagian Audit internal: pimpinan audit internal harus mengelola bagian audit internal secara cepat. (Hiro Tugiman, 16-19:2001)

Diharapkan dengan adanya standar audit internal dapat membuat auditor internal secara penuh memberikan peran sebagai: mitra, konsultan perusahaan, memiliki pandangan holistik, visi bisnis, partner auditor eksternal, memberikan nilai tambah, dan pendorong perubahan. Sehingga fungsi pengendalian dalam perusahaan dapat berjalan dengan baik.

Pengendalian internal yang baik yang dilaksanakan auditor internal diharapkan dapat mendukung terwujudnya GCG pada perusahaan. Penerapan GCG yang efektif pada BUMN memberikan sumbangan yang penting dalam memperbaiki kondisi perekonomian, serta menghindari terjadinya krisis dan kegagalan serupa di masa depan.

Sumbangan tersebut dapat dilakukan secara kolektif oleh pekerja-pekerja di dalam tingkatan-tingkatan yang berbeda. Upaya melakukan GCG dapat dilakukan jika masing-masing pihak dalam perusahaan menyadari perannya untuk mewujudkan GCG, Audit Internal dapat berperan dalam GCG diungkapkan menurut Iman S. Tunggal dan Amin W. Tunggal (2002: 49) yaitu:

1. Sebagai Compliance auditor

a. Bertanggungjawab kepada dirktur utama/ Chief Executive Officer (CEO) dan mempunyai akses kepada komite audit.

b. Memonitor pelaksanaan kepatuhan terhadap kebijakan prosedur perusahaan

c. Mengevaluasi sistem pengendalian internal dan bertanggungjawab kepada komite audit.

d. Memelihara dan mengamankan aktiva perusahaan dan menangani faktor resiko secara baik.

e. Menelaah kinerja melalui mekanisme audit keuangan dan operasional 


\section{Sebagai internal business consultant}

a. Membantu komite audit dalam menilai resiko dan member nasihat kepada pihak manajemen

b. Melaksanakan fungsi konsultan dan memastikan pelaksanaan GCG

c. Menelaah peraturan corporate governance minimal setahun sekali.

Adapun menurut Hiro Tugiman, menyebutkan bahwa fungsi audit internal memberikan sumbangan bagi GCG sebagai berikut:

Organisasi profesi Internal Auditors Indonesia yang terdiri atas The Institute of Internal Auditors (IIA)- Indonesia Chapter; Forum komunikasi Satuan pengawasan Intern (FKSPI) BUMN/BUMD; Yayasan pendidikan Internal Audit (YPIA); Dewan Sertifikasi Qualified Internal Auditor (DS-QIA) dan perhimpunan Auditor Internal Indonesia (PAII) berkeyakinan bahwa fungsi internal audit (satuan pemeriksaan intern) yang efektif mampu memberikan sumbangan penting dalam meningkatkan proses Corporate Governance, pengelolaan resiko, dan pengendalian manajemen. Internal auditor merupakan dukungan penting bagi Komisaris, Komite Audit, Direksi, dan Manajemen Senior dalam membentuk fondasi bagi pengembangan corporate governance.(Position Paper \# 1/2003, Yogyakarta, 29 juli 2003).

Berdasarkan Keputusan tersebut dapat dilihat adanya keterkaitan Audit internal dengan GCG. Keterkaitan audit internal dengan GCG bisa dilihat dari definisi, tujuan, ruang lingkup, wewenang, tugas dan tanggung jawab audit internal dihubungkan dengan prinsip-prinsip GCG.

Dilihat dari definisinya, audit internal membantu organisasi dalam mencapai tujuan, mengevaluasi dan meningkatkan keefektifan manajemen resiko, pengendalian serta proses pengaturan dan pengelolaan organisasi. Dari definisi tersebut tersirat tujuan audit internal, yaitu membantu seluruh anggota manajemen agar dapat melaksanakan tanggungjawabnya secara efektif, dengan jalan memberikan analisa, penilaian, rekomendasi, saran, dan keterangan dari operasi atau aktivitas perusahaan yang diperiksanya.

Sudah tampak suatu hubungan antara audit internal dengan prinsip-prinsip GCG. Semua aktivitas, tujuan dan ruang lingkup audit internal dapat mendukung GCG.

Adapun Pengertian GCG menurut OECD dalam Sutojo dan E John (2008: 2) yaitu :

Corporate governance adalah sistem yang dipergunakan untuk mengerahkan dan mengendalikan kegiatan bisnis perusahaan. Corporate governance mengatur pembagian tugas, hak kewajiban mereka yang berkepentingan terhadap kehidupan perusahaan, termasuk para pemegang saham, Dewan Pengurus, para manajer, dan semua anggota stakeholder.

Sesuai dengan pengertian GCG yaitu struktur, sistem serta proses yang membuat prinsip GCG dapat diterapkan. Adapun prinsip GCG secara umum sebagai berikut: (1) Transparansi: Mewajibkan adanya suatu informasi yang terbuka, tepat waktu, serta jelas dan dapat diperbandingkan, yang menyangkut keadaan keuangan, pengelolaan perusahaan, dan kepemilikan perusahaan; (2) Akuntabilitas: Menjelaskan peran dan tanggung jawab, serata mendukung usah untuk menjamin penyeimbangankepentingan manajemen dan pemegang saham, sebagaiman diawasi oleh Dewan Komisaris; (3) Pertanggungjawaban: Memastikan dipatuhinya peraturan-peraturan serta ketentuan yang berlaku sebagai cermin dipatuhinya nilai-nilai sosial; (4) Kewajaran: Keadaan dan kesetaraan dalam memenuhi hak-hak stakeholder yang timbul berdasarkan perjanjian dan perundangan yang berlaku. Adrian Sutedi (2011: 4) 
Sistem Corporate governance yang baik memberikan perlindungan efektif kepada para pemegang saham dan pihak kreditor, tentunya untuk mencapai tujuan perusahaan. Apabila prinsip-prinsip tersebut dilaksanakan tentunya tujuan dari GCG dapat dipenuhi dengan baik. Adapun menurut FCGI (dalam Bismack, 2005: 59) mengemukakan secara rinci tujuan dari GCG meliputi: (1) Menciptakan atau meningkatkan keunggulan kompetitif; (2) Dapat bekerja secara efesien dan mencergah fraud dan mal praktek; (3) Melindungi kepentingan para pemegang saham dan stakeholder yang lain; (4) Meningkatkan nilai perusahaan; (5) Mengurai resiko antara lain dengan tidak melanggar undang-undang dan peraturan; (5) Mengurangi kemiskinan melalui pertanggung jawaban sosial.

Prinsip diatas diharapkan dapat memberikan manfaat bagi perusahaan. Dengan mewujudkan GCG, membuat perusahaan menjadi kuat dan kompetitif sesuai dengan postur perusahaan masa depan. Dengan manfaat yang diperoleh dari GCG diharapkan perusahaan dan pemerintah dapat berjalan sesuai dengan kaidah praktik yang sehat di segala bidang.

Perwujudan GCG ternyata sangat membutuhkan peran akuntan perusahaan, salah satunya yaitu auditor internal dimana auditor memeriksa dan mengevaluasi sistem akuntansi disamping seberpa jauh kebijakan dan program kerja manajemen dijalankan. Perwujudan GCG yang efektif menciptakan sistem yang dapat menjaga keseimbangan pengendalian perusahaan sehingga dapat ditekan seminimal mungkin peluang terjadinya korupsi dan penyalahgunaan wewenang masing-masing organ perusahaan.

Dapat disimpulkan bahwa dengan adanya audit internal yang sesuai dengan standar profesional audit internal maka dapat membantu BUMN dalam menerapkan prinsip- prinsip GCG yang baik seingga tujuan perusahaan dapat dicapai.

Berdasarkan uraian di atas maka menggambarkan kerangka pemikiran sebagai berikut:

Gambar 1.1

Kerangka Pemikiran

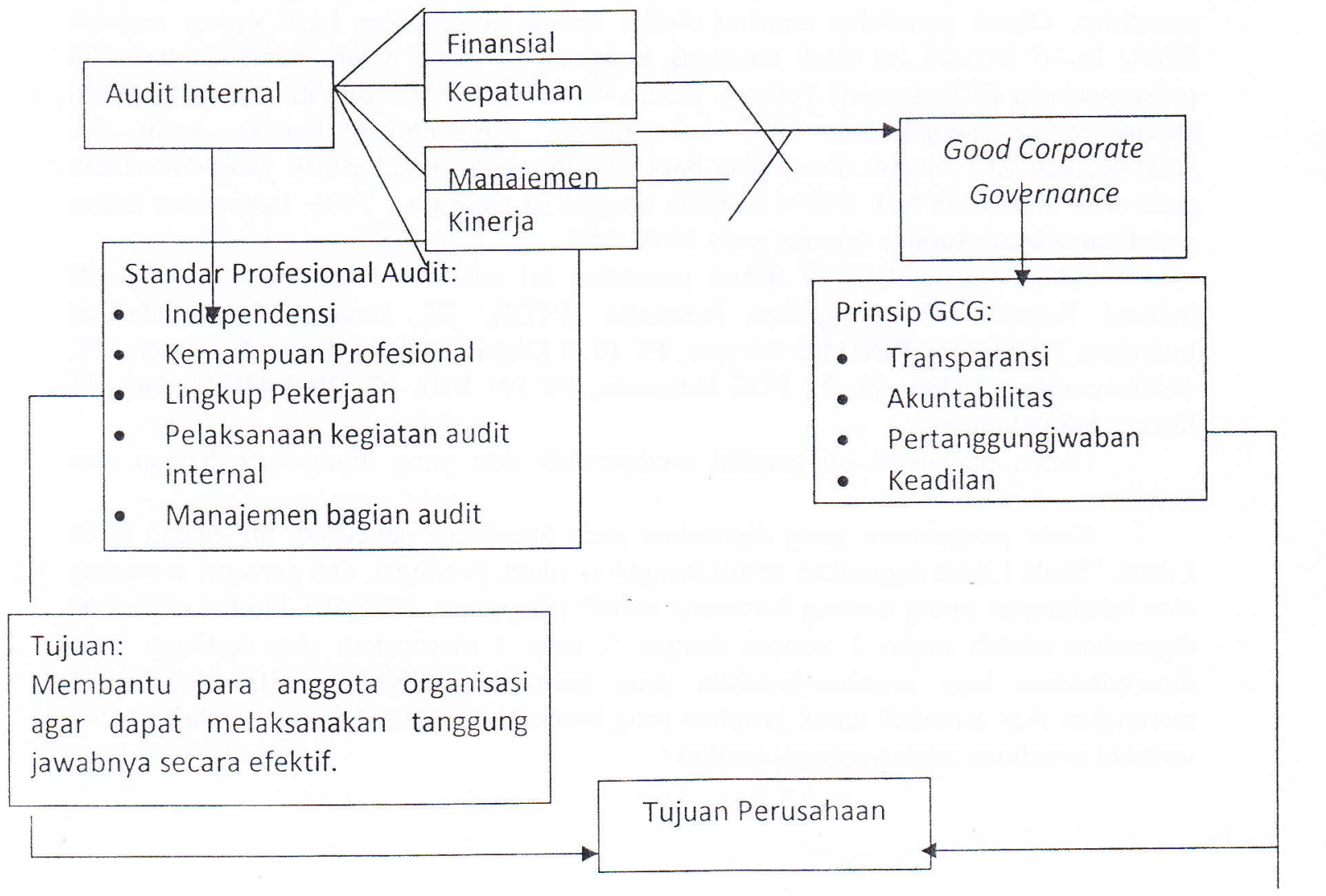

Jurnal Akuntansi Riset, Prodi Akuntansi UPI, Vol. 4, No. 2 
Berdasarkan rumusan masalah yang telah dipaparkan sebelumnya, maka hipotesis dari penelitian ini adalah" auditor internal mempunyai pengaruh positif terhadap Good Corporate Governance".

\section{Metode Penelitian}

Metode penelitian yang digunakan penulis dalam penelitian ini adalah metode deskriptif yaitu penelitian terhadap masalah-masalah berupa fakta-fakta saat ini dari suatu populasi.

Tujuan penelitian deskriptif ini adalah untuk menguji hipotesis atau menjawab pertanyaan yang berkaitan dengan current status dari subyek yang diteliti. Penelitian deskriptif berkaitan dengan opini (individu, kelompok atau organisasional), kejadian atau prosedur.

Penelitian merupakan suatu cara yang dapat dilakukan untuk menemukan suatu jawaban, untuk membuktikan sesuatu hal atau untuk memecahkan masalah. Dalam penelitian digunakan metode tertentu yang dapat membantu agar penelitian tersebut dapat tercapai. Desain Penelitian memerlukan perencanaan agar penelitian yang dilakukan dapat berjalan dengan baik dan sistematis.

Berdasarkan pada sifat penelitian yang bersifat deskriptif-verivikatif, maka penelitian metode penelitian yang digunakan adalah metode kausalitas. Hubungan kausal adalah hubungan yang bersifat sebab akibat. Jadi disini variabel terdapat variabel independen (variabel yang mempengaruhi) dan variabel dependen (dipengaruhi). Sugiyono (2010: 56)

Dengan metode ini peneliti berusaha menemukan hubungan sebab akibat antara faktor-faktor tersebut atau faktor lainnya. Penelitian ini dimaksudkan untuk memberikan penjelasan dengan cara melakukan pengukuran secara cermat terhadap fenomena tertentu dan menjelaskan hubungan kausal antara variabel-variabel melalui pengujian hipotesis dengan menggunakan tes statistik.

Populasi dalam penelitian ini adalah seluruh BUMN pusat wilayah Kota Bandung. Terdapat 10 BUMN pusat wilayah Kota Bandung yang dipilih sebagai penelitian, Obyek penelitian tersebut dipilih karena berdasarkan hasil survey majalah SWA, ke-10 BUMN ini tidak termasuk kedalam 26 besar dalam penilaian terhadap prinsip-prinsip GCG kecuali Telkom. Selain itu ke-10 BUMN dipilih sebagai populasi karena sudah menjalankan GCG sebagaimana pembentukan komite Audit dan pelaksanakan GCG sudah diwajibkan bagi BUMN secara keseluruhan yang didasarkan pada surat keputusan NO: KEP-41/M/203 tanggal 23 Desember 2003. Responden dalam penelitian adalah Auditor Internal pada 10 BUMN.

Adapun nama BUMN dalam penelitian ini adalah sebagai berikut: PT LEN industri Persero, PT. Dirgantara Indonesia (PTDI), PT. Industri Telekomunikasi Indonesia (INTI), PT PINDAD Persero, PT PLN Distribusi Jawa Barat \& Banten, PT. Telekomunikasi Indonesia, PT POS Indonesia, PT PN VIII, PT BIOFARMA,dan PT Kereta Api Indonesia.

Dalam penelitian ini peneliti memperoleh data yang diperlukan dengan cara kuesioner.

Skala pengukuran yang digunakan pada kuesioner penelitian ini adalah skala Likert. "Skala Likert digunakan untuk mengukur sikap, pendapat, dan persepsi seseorang atau sekelompok orang tentang fenomena sosial" (Sugiyono, 2005:86). Urutan nilai yang digunakan adalah mulai 1 sampai dengan 5 , nilai 5 merupakan skor tertinggi yang diperuntukkan bagi jawaban-jawaban yang bermakna sangat positif, dan nilai 1 merupakan skor terendah untuk jawaban yang bermakna negatif. Ukuran penilaian untuk variabel penelitian adalah sebagai berikut : 
Table 2.1

Skor Pernyataan

\begin{tabular}{|c|c|c|}
\hline No & Kriteria & Skor \\
\hline 1 & Selalu (SL) & 5 \\
\hline 2 & Sering (SR) & 4 \\
\hline 3 & Kadang-kadang (KK) & 3 \\
\hline 4 & $\begin{array}{c}\text { Hampir Tidak Pernah } \\
\text { (HTP) }\end{array}$ & 2 \\
\hline 5 & Tidak Pernah (TP) & 1 \\
\hline
\end{tabular}

(Sugiyono, 2010: 133)

Adapun analisis data yang dilakukan dalam penelitian ini adalah sebagai berikut :

Uji validitas yang dilakukan dengan menggunakan rumus korelasi Product Moment Pearson sebagai berikut:

$$
r=\frac{n\left(\sum x y\right)-\left(\sum x\right)\left(\sum y\right)}{\sqrt{\left\{n \sum x^{2}-\left(\sum x\right)^{2}\right\} \cdot\left\{n \sum y^{2}-\left(\sum y\right)^{2}\right\}}}
$$

Masri Singarimbun (137: 2011)

Keterangan :

$\mathrm{r}=$ koefisien korelasi pearson

$\mathrm{x}=$ Skor pernyataan $\mathrm{ke}-\mathrm{i}, \mathrm{i}=1,2,3, \ldots, \mathrm{n}$

$y=$ Skor total pernyataan

$\mathrm{n}=$ Jumlah sampel

Uji reliabilitas dalam penelitian ini menggunakan metode Koefisien Alpha Cronbach's dengan rumus:

$$
r_{11}=\left(\frac{k}{k-1}\right)\left(1-\frac{\sum \sigma b^{2}}{\sigma t^{2}}\right)
$$

Keterangan :

$r_{11}$ : reliabilitas instrumen

$\mathrm{k}$ : banyak butir pertanyaan

$\sigma t^{2}$ : varian total

$\sum \sigma b^{2}:$ jumlah varian butir

\section{Rancangan pengujian hipotesis}

\section{a. Penetapan Hipotesis Nol dan Hipotesis Alternatif}

Penetapan hipotesis nol dan hipotesis alternatif digunakan dengan tujuan untuk mengetahui ada atau tidaknya pengaruh positif antara dua variabel $\mathrm{X}$ dan variabel $\mathrm{Y}$, dan seberapa besar pengaruh tersebut. Pada umumnya formula hipotesis seperti ini jika $\mathrm{H}_{0}$ ditolak maka $\mathrm{H}_{\mathrm{a}}$ diterima. Adapun masing-masing hipotesis adalah sebagai berikut:

$\mathrm{H}_{\mathrm{O}}=$ Tidak terdapat pengaruh positif antara audit internal dengan GCG

$\mathrm{H}_{\mathrm{A}}=$ Terdapat pengaruh positif antara audit internal dengan $\mathrm{GCG}$

\section{b. Pemilihan Tes Statistik dan Perhitungan Tes Statistik}

Hipotesis dalam penelitian ini akan diuji dengan menggunakan analisis korelasi Rank Spearman dengan rumus sebagai berikut: 
$r_{s}=\frac{6 \sum d i^{2}}{n^{3}-n}$

(Sugiyono, 2010:357)

Dengan ketentuan :

$\mathrm{rs}=$ Koefisien korelasi rank spearman yang menunjukkan keeratan hubungan antara unsur-unsur variabel $\mathrm{x}$ dan $\mathrm{y}$

$\mathrm{di}=\quad$ selisih rank data-data variabel $\mathrm{x}$ dan $\mathrm{y}$

$\mathrm{n}=$ Banyaknya subjek yang diteliti

Dari koefiesien yang dihasilkan dapat diinterprestasikan derajat hubungan

Untuk lebih memudahkan dalam melakukan pengujian statistik dengan analisis

korelasi Rank Spearman maka peneliti menggunakan alat bantu yakni SPSS v.20.0 (Statictical Program for Social Science).

\section{c. Pengujian Kriteria}

Setelah menghitung koefisien korelasi maka selanjutnya dilakukan pengujian kriteria. Kriteria pengujian yang dipakai dalam penelitian ini berpedoman pada ketentuan pemberian interpretasi terhadap koefisien korelasi menurut Sugiyono. Adapun pedoman tersebut adalah sebagai berikut:

Tabel 2.2

Pedoman untuk memberikan Interpretasi terhadap Koefisien Korelasi

\begin{tabular}{|c|c|}
\hline Interval koefisien & Tingkat Hubungan \\
\hline $0,00-0,199$ & Sangat rendah \\
\hline $0,20-0,399$ & Rendah \\
\hline $0,40-0,599$ & Sedang \\
\hline $0,60-0,799$ & Kuat \\
\hline $0,80-1,000$ & Sangat kuat \\
\hline
\end{tabular}

(Sugiyono, 2010: 216)

\section{d. Menghitung Koefisien Determinasi}

Setelah diketahui nilai koefisien korelasi (r) yang memperlihatkan derajat atau kekuatan korelasi antara variabel maka akan dihitung koefisien determinasi $\left(\mathrm{k}_{\mathrm{d}}\right)$ yang dapat memperlihatkan berapa persen variasi variabel $X$ akan mempengaruhi variabel $Y$ dengan rumus koefisien determinasi $=r^{2} \times 100 \%$.

\section{Hasil Penelitian dan Pembahasan}

Berdasarkan hasil pengujian diketahui bahwa nilai koefisien korelasi sebesar 0.711 dan sesuai dengan pedoman pemberian interpretasi koefisien korelasi yang telah dikemukakan bahwa nilai sebesar 0.711 merupakan koefisien yang tergolong memiliki tingkat hubungan yang kuat karena nilai ini ada pada interval 0,60-0,799. Pengujian hipotesis dilaksanakan untuk menguji kebenaran dari hipotesis yang telah diajukan pada penelitian. Uji hipotesis yang dilaksanakan dengan menguji nilai dari koefisien korelasi yang didapatkan dengan mempertimbangkan tingkat korelasi hasil tersebut untuk dapat digeneralisasikan terhadap populasi. Pengujian signifikansi koefisien korelasi yang dilaksanakan dengan menggunakan nilai sig. Nilai sig. penelitian ini adalah 0,032 lebih kecil dari 0,05 $(0,032<0,05)$, maka Hipotesis (Ho) ditolak dan Hipotesis Alternatif (Ha) dapat diterima. Dengan demikian dapat disimpulkan bahwa terdapat pengaruh positif antara audit internal dengan GCG.

Koefisien korelasi sebesar 0,711 memperlihatkan bahwa tingkat kekuatan hubungan antara variabel profesionalisme auditor internal terhadap variabel 
pengungkapan temuan audit 0,711 selanjutnya peneliti akan menghitung koefisien determinasi yang mampu memperlihatkan tingkat persentase variasi atau naik turunnya variabel audit internal dalam mempengaruhi variabel Good Corporate Governance sebagai berikut:

$\mathrm{Kd}=\mathrm{r}^{2} \times 100 \%$

$=(0,711)^{2} \times 100 \%$

$=50.55 \%$

Berdasarkan hasil perhitungan di atas diketahui bahwa nilai koefisien determinasi adalah sebesar $50.55 \%$ yang mengindikasikan bahwa naik dan turunnya variabel GCG adalah dipengaruhi oleh naik turunnya variabel audit internal sebesar $50.55 \%$.

\section{Simpulan}

Berdasarkan analisis yang telah peniliti lakukan dan hasil penelitian yang telah peneliti dapatkan pada sembilan BUMN di Kota Bandung mengenai Pengaruh Audit Internal terhadap Good Corporate Governance, maka dapat disimpulkan bahwa:

1. Audit Internal pada sembilan BUMN di Kota Bandung sudah menjalankan kegiatan auditnya sesuai standar, hal ini di indikasikan dengan dilaksanakannya lima dimensi audit internal, yakni Independensi, ruang lingkup perkerjaan, kegiatan pemeriksaan dan manajemen audit internal. Namun dalam dimensi yang diteliti, Kemampuan Profesional memiliki skor yang paling rendah.

2. Good Corporate Governance pada sembilan BUMN di Kota Bandung pada telah dilaksanakan sesuai dengan prinsip. Hal ini terlihat dari pelaksanaannya terhadap prinsip GCG, yakni transparansi, akuntabilitas, pertanggungjawaban, kewajaran/keadilan.

3. Berdasarkan uraian dan perhitungan yang telah dikemukakan pada Bab IV dapat disimpulkan bahwa audit internal berpengaruh terhadap GCG dan mempunyai pengaruh yang positif kuat.

\section{Saran}

Setelah melakukan penelitian dan memperoleh data-data serta memberikan kesimpulan atau hasilnya, peneliti mencoba memberikan saran-saran yang diharapkan dapat lebih meningkatakan usaha dalam pencapaian GCG yang sesuai dengan harapan perusahaan. Saran tersebut diantaranya:

1. Auditor internal yang terdapat pada sembilan BUMN di Kota Bandung sudah melakukan aktivitas auditnya berdasarkan standar profesional audit internal. Namun berdasarkan hasil penelitian auditor internal pada BUMN pada dimensi Kemampuan Profesional memiliki skor paling rendah diantara dimensi lainnya. Dalam meningkatkan kemampuan profesionalnya, sebaiknya auditor internal meningkatkan kemampuan profesional dengan mengikutsertakan auditor dalam konferensi, seminar, kursus, program pelatihan, berpartisipasi dalam perkumpulan dalam profesi sehingga auditor internal dapat up to date dengan perkembangan auditing yang terus berkembang.

2. Peneliti sangat menyadari bahwa dalam penyusunan penelitian ini masih terdapat berbagai kelemahan dan kekurangan. Oleh karena itu, untuk peneliti selanjutnya diharapkan melakukan penelitian dengan lebih mendalam, yang tidak menjadikan kuesioner sebagai data penelitian. Selain itu Peneliti yang tertarik dengan masalah serupa, sebaiknya melakukan penelitian terhadap subjek lain yang lebih luas ataupun hal lainnya yang dapat meningkatkan GCG, yaitu pengendalian internal, kinerja auditor, komite audit. 


\section{Daftar Pustaka}

Adrian Sutedi. (2011). Good Corporate Governance. Jakarta: Sinar Grafika.

Agoes Sukrisno. (2008). Auditing (Pemeriksaan Akuntan) cetakan ke 4. Jakarta: Lembaga penerbit fakultas ekonomi Universitas Indonesia.

Bismarck Dasano H. (2005). "Pengaruh Audit Internal terhadap perwujudan Good Corporate Governance". Skripsi.Bandung: FE Universitas Padjadjaran.

Hiro Tugiman. (2006). Standar Profesional Audit Internal Cetakan ke 5. Jakarta: Kansius

Konsorsium Organisasi Profesi Audit Internal. (2004). Standar profesi audit internal :Jakarta

Masri Singarimbun dan Sofyan Effensi. (2011). Metode Penelitian Survai. Jakarta: Pustaka LP3ES.

Sawyer Laurance, Dittenhofer Mortimer, Scheiner James. (2009). Audit Internal Edisi 5 Buku 1 (Penerjemah Desi Adhariani). Jakarta. Salembaempat.

Sugiyono. (2010). Metode Penelitian Bisnis. Bandung: Alfabeta

Sutojo, Siswanto dan Aldrige, E John. (2008). Good Corporate Governance. Jakarta: PT. Damar Mulia Pustaka

Thomas S. Kaihatu. (2006). "Good Corporate Governance dan Penerapannya di Indonesia". Jurnal Manejemen dan Kewirausahaan, VOL.8, No. 1.

Widjadja, Amin, Tunggal. (2005). Internal Auditing (Suatu Pengantar). Jakarta. Havarindo 